研究資料

\title{
『サラダ記念日』が台湾に与えた影響
}

\author{
Yenhung LAI(頼衍宏 : Associate Professor of Department of Japanese Language \\ and Literature, Providence University) \\ 四yhlai@pu.edu.tw
}

(台湾)静宜大学日本語文学系副教授。東京大学で2008年「日本語時代の台湾短歌——結社を中心にした資料研 究て博士号取得。比較文学。主著に『日本文学管見——和習·短歌·作品論』(新北：尚昂文化. 2015)、「台 湾における皇民化運動——政策の形成と短歌の広がり」『跨境/日本語文学研究第9号』(ソウル：高麗大学校日本 研究センター, 2019)など。

\section{The Influences of Salad Anniversary on Taiwan}

The book Salad Anniversary (1987) by Tawara Machi sold a million copies. This study attempts to illustrate the possible influences of Salad Anniversary on Taiwanese people's creative activities, through a comparative literary analysis. To be more specific, I'd like to explore the context and significance of the reception of Tawara Machi's literary works in two fields, namely Taiwanese tanka poetry and Chinese pop music platforms.

Keywords Hwa-Kang World of Tanka(華岡歌壇), Taiwanese World of Japanese Tanka Poets(台湾歌壇), Winnie Hsin(辛曉琪), Scent(味道), Chien Yao(姚謙) 


\section{1 はじめに}

俵万智『サラダ記念日』(1987、東京：河出書房新社)というミリオンセラーに ついては、好評もあれば批判もある。前者の代表的なのは日本の歌人穂村弘が執 筆した「俵万智」のの口語会話体を大胆に駆使した文体の魅力が、描かれた場面や 感情の普遍性と相俟って、短歌になじみのない読者をも強く惹きつけたのであ る」という点に尽きるだろう。後者は、日本歌壇の評論家である沢口芙美が執筆 した「俵万智」2で示された「詩的修辞力の弱さ、文学的濃のなさ」という「弱点」が ある。また、台湾の研究者彭春陽の書いた「日本的国民女歌人俵万智」ににおける 「旧制度の擁護者たちは、過度の口語体が詩の言語を破壊し、即物式の描写も深 みを欠いている」という問題も横たわっている。しかし、「歌壇の内と外とに大 きな影響を与えた」と皇をらエネルギ一は否めない事実である。ここでは、主に 材源論の立場から、俵ブームが台湾の創作活動のためにどのような原資を提供し たのか、解明に努めたい。

\section{2 受容の実例}

以下、二つの歌壇(短歌と流行歌)からこれについて検証してみたい。

1 大島史洋(他編) 『現代短 歌大事典』（東京：三省 堂, 2000), pp.384-385.

2 浅井清(他編)『短歌』(東 京：明治書院，2000）。 p.386.

3『世界文学』6, 麦田, 2002 12), p.114。原文：「衛 道人士対俵万智大加撻 伐, 認為過份的白話, 破壊了

詩的語言, 㶨物式的描 写, 欠缺深度」

4 島津忠夫『現代短歌・内 と外』(東京：雁書館， 1992), p.49

5 孤蓬万里『台湾万葉集 中巻』(台北：点建堂, 1988), pp.2-3

6 録音テープは細川咫港 によるものである。

\section{1 短歌界}

孤蓬万里(1926 1998) は台湾版『台湾万葉集』(非売品)の上梓に際して、「今評判 になつて居る「俵万智」の「サラダ紀念日」が日本の現代短歌を代表するものである とする人たちには、この三巻を読んで戴きたいと希ふものである」 ${ }^{5}$ 書いてい る。

次いで、「東洋文化研究会じやすみん俱楽部」で講演 ${ }^{6}$ (1993年8月21日、銀座並 木通りのニューキャッスルにて)を行った際に、孤蓬万里は「俵万智さんなどが やられている「ライトバース」という新しい傾向」を取り上げて、その特色を次の ように述べている。

俵万智さんはそのわりと、その、そういった会話調とかいったそういう のを取り入れてです悋。で、三十一文字の間にだいたい半分くらい口語調を 入机て恐らくそういったところ括弧入れるんだけど、それはもう括弧も省 略してね。

その基準に符合した俵の歌が「寒いね」と話しかければ「寒いね」と答える人の 
7 俵万智『サラダ記念日』 (東京：河出書房新社。 1987), p.18.

8 孤蓬万里『台湾万葉集 物語』(東京：岩波書店， 1994), p.24.

9 吳建堂『花をこぼして。 （台北：尅建堂, 1981）。 p.77.

10 (東京：朝日新聞社， 1995), p.288

11 『台北歌壇』127(孤蓬 万里, 1998.3), p.71.

12 蕭翔文『三つの祖国』 (台北: 蕭翔文 2006), p.124.

13 頼衍宏「専訪「台北歌壇 前任代表高阿香女士」 (『留日同学会刊』11,日 本奨学金留学生聯誼 会, 2005.11), p.14 原文：「俵小姐的暢銷 書『沙拉紀念日』我在 会晤前已経先行読過」
いるあたたかさ」7である。孤蓬万里が編著した「台湾万葉百人一首」8を見ても、 徐奇璧の「「八イありがと」銭渡す吾に「八イありがと」と運ちやんも云うとある小 春日」が含まれており、「この一首、ちょっとしたライトバース調」と批評してい る。確かに会話句十同じ会話句十暖かく詠み収めるという構成法が共通してお り、「ライトバース調」という選評が当を得ていると言える。一見して俵歌の詠 み方に従って徐歌が出来たように考えられてしまうだろう。しかし、徐歌の初 出「「八イ、ありがと」銭渡す吾に「八イ、ありがと」運ちやんも云子、とある小春 日」きを確かめると、俵歌に先んじたものであった。つまり、孤蓬万里の指摘は、 俵歌以前に発表済の徐歌を、俵歌の持つライトバース性が濃厚に見出される作品 として解釈するという、いささか時系列を錯䛊した批評であったのである。

一方、『台湾万葉集』は『サラダ記念日』と同等に見られる傾向がある。当時集 英社編集長である細川咫港の厚意により集英社「台湾万葉集」単行本愛読者カード を調査することができた。そのうち、神奈川県在住の堀江征太郎(1994年当時51 歳は「技巧に走らず技直に日常を詠んでいて、サラダ記念日と同じ感動を受けた」 という共通性を見出している。また、無署名者も「読んで面白く、かつ、楽し い。わかりやすい。（日本の歌人は、むつかしい歌を詠んでさっぱりわからな い。かと思うと、某女史のような会話調の青春短歌がもてはやされ、この本は 新鮮だ!! )」としており、俵万智ブームと対比している。そうした観点と同調す るように、大岡信『大岡信の日本語相談』 ${ }^{10}$ の巻末座談会を見ると、丸谷才一の「戦 後の日本文学における短歌の二大事件というのは、一つは俵万智さんの出現、も うひとつは『台湾万葉集』ではないかしら。もう一つあると三題噺になるんだけ ど……(笑い)」という発言がある。孤蓬万里「玉石混淆(亡き妻に捧げる)」11は丸 谷の位置づけ方を重点的に引いて、「皆が笑いで答えて居るのは嬉しかつた」と している。出版部数だけを比べると、二百万部を超えた『サラダ記念日』に対し て、集英社再版の『台湾万葉集』は結果的に六刷しかない。かなり評判に出ている が、とても同列に語れるものではない。孤蓬万里が嬉しく感じたのは、出版部 数のわりにべストセラーとともに並び称される名声を得たことであろう。た だ、『台湾万葉集』に対して、台湾歌壇の重鎮である蕭翔文が「殖民と白色恐怖を 経し叫びずっしりと重し『台湾万葉集』」2 と評していることも見逃すことができ ない。内容的に『サラダ記念日』の軽さと比較すると、『台湾万葉集』の重さが浮き 彫りになりそうである。

孤蓬万里が急逝した後、「台北歌壇」(後に「台湾歌壇」と改称された）の第二期 代表(1999年1月 2003年12月)に選ばれた高阿香は1999年11月の8日間「台湾万葉集 女流歌人訪日団」を引率した。11月19日に俵万智と交流することになった。「俵さ んのベストセラー『サラダ記念日』は、面会する前にすでに読了しておいた」 ${ }^{13}$ と いう回顧からすれば、事前準備が進められていた。日本交流協会（当時の通称 
で、現・公益財団法人日本台湾交流協会）に提出した高阿香「台湾万葉歌人の訪日 記(1)」14によると、「俵万智さんは私の半分の齢しかない若い女性、睫毛の長い大 きな眼をぱちぱちさせ乍らの応答は燷としていて」という第一印象が語られてい る。続いて「台北歌壇 5 名の作品を」「選んで批評なさった」という実力を見せ、「若 い人達だけの結社を作って新しい短歌の詠み方を試みたい思いませんか」という 高の問いに対して、「い、え年輩の人の中で大事にされると言うのもよい事だと 思います」という俵の答えがあったという。そして、「だんだん打ち解けて俵万 智さんとの懇談は愉快な䨌囲気の中に終った」と和気蔼々裡に終了した、と述べ られている。

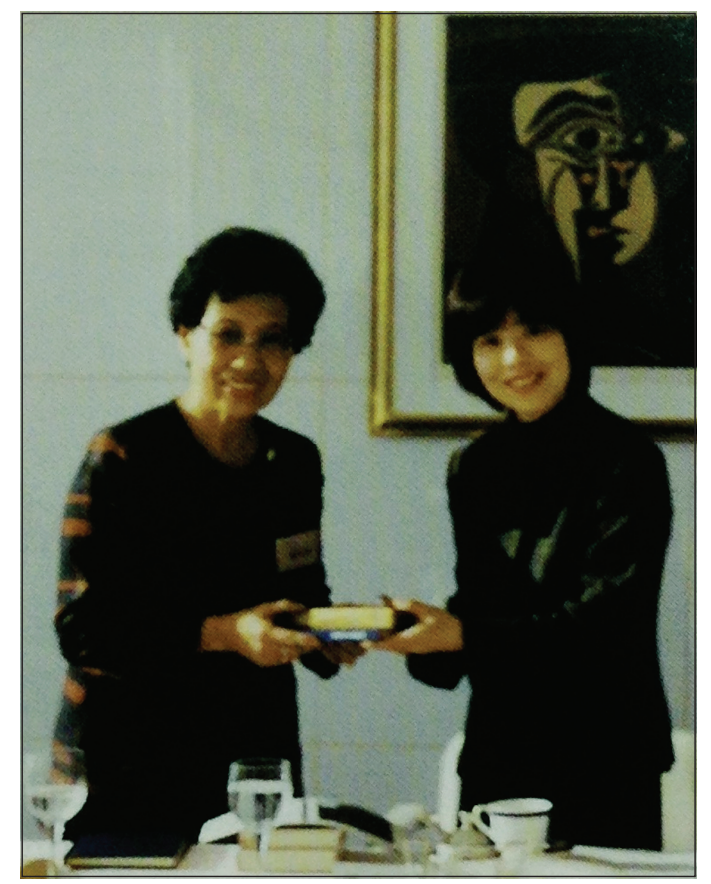

図1 高阿香と俵万智 ${ }^{15}$

一方、「口語にて短歌を作杖ば何となく楽しいと言へば万智さん笑ふ」という 作品も団員である林美の歌集 ${ }^{16} に$ 収録されている。1990年代後半の台湾の歌壇に とって、交流すべき女流歌人リストのうち俵が最上位に置かれているのである。

俵万智の「家族への葉書」という文章は国際学友会日本語学校『進学する人のた めの日本語中級』(2000、東京：国際学友会)に採録されており、それがまた『進学 日本語中級 I』(2002、台北：大新)に収められることで、台湾の日本語教育の現 場でも採用されている。読解力を養成する中で、台湾の一般的な学習者も俵のラ 
17 注8、p.25.

18 吳建堂『文武仁の旅』 （台北：兝建堂, 1981), pp.191-193. 初出は『山 の辺』10-5(山の辺短 歌会, 1979.5)。正式 の学科名は「東方語文 学系」であり、今の「日 本語文学系」の前身で ある。

19 蔡華山「「台湾歌壇」の 伝承的考察」(『台湾日 本語文学報』20, 台湾日 本語文学会, 2005.12) p.26.

20 蔡華山(撰)「華岡歌壇」 (『中日文化』21, 中国 文化大学日文系日研所, 2002.5), p.273. 所収

21 注 7, p.125

22 注 20, p.276. 所收

23 『中日文化論』24(中国文 化大学日文系日研所, 2006.6), p.135.

24 注7, p.16.
イトバースに触れる機会があるのである。この際、創作力を追求する実例とし て「台湾万葉百人一首」の歌人の一人である蔡華山に関する「若い台湾の学生に短 歌を作らす試みをつづけている」 ${ }^{17}$ という紹介は注目に值する。その指導は前期 と後期に分けることができる。前期に関しては「最近、台北歌壇の同人の一人で ある蔡華山氏が、その教鞭を執って居る東呉大学東方語学系に於て、学生に和歌 らしきものを作らせる事に成功して居る」 ${ }^{18}$ と孤蓬万里に認められている。その 代表作にざっと目を通すと、于乃明の「口聞か女竹馬の友よ何故聞か女君に告げ たき事の多きに」をはじめ文語脈の歌が多数を占めている。蔡華山「「台湾歌壇」の 伝承的考察」19によると、孤蓬万里側から「いろいろとアドバイスしてくれた」お 蔭で成果をあげることができたが、「一番大きな収穫は学生達に「や机ばできる」 という信念を持たせることであろう」という。後期に至っては、口語脈を重視す る方針に転換した。中国文化大学で筆札を授けている蔡華山の特別講演「台湾に おける和歌の伝承一日本語学科学生の和歌について」(2001年8月18日、中華民国 日本語文学会第151次例会)を聞いた際に、筆者は講演内容を録音しておいた。そ れによると、蔡は『サラダ記念日』を礼賛するばかりでなく、俵ファンであるこ とを打ち明けている。

口語、しかも五七五でまとめてしかもポエジーが非常に強い。日常の生 活を我々に伝えているこの人今悋、本をもうたくさん書いてるね。もう 35 冊くらいになるまあ、そのうち私は 25 冊くらい持ってる。

同講演で「俵万智以降の歌」として、北台湾の大学三校（政治大学・文化大学・ 東吳大学）の力作を褒めている。そのうち、林璟淳の「偶然に知り合ってから君 のこと忘れられずに記念日となる」20を読むと、女性が男性を「君」と呼び、それ で「記念日」が決まったような詠み方は、『サラダ記念日』の表題歌「「この味がい い权と君が言ったから七月六日はサラダ記念日」と同様である。もう少し補足 すると、次の二首が目を引く。

〈1〉「いつ帰る」「まだ決めてない」新年もこんな電話をしている親子(徐国 章) ${ }^{22}$

〈2〉「ただいま！」と声を掛けても「おかえり」と答える声のない寂しさよ(王 薇婷 $)^{23}$

『サラダ記念日』24の電話詠—「「また電話しろよ」待ってろ」いつもいつも命 令形で愛を言う君」がある。「問い1」+「問い2」を連発し、最後に体言止めで終わ る。〈1〉も電話詠であり、しかも「問い」+答え」で詠み起こして、体言止めで詠 み収めている。俵歌の構造を踏まえつつ、俵の恋愛の歌を徐は親子愛の歌へと改 
作したのではないだろうか。〈2〉の場合、「挨拶の引用+動詞、答えの引用+動詞+ 名詞+存否+形容詞の名詞化」という構成法は、「「寒い㸚」と話しかければ「寒いね」 と答える人のいるあたたかさ」25を参照した結果だと考えられる。俵万智「家族へ の葉書」26を確かめると、「寒い权」詠についての自解として「私は寂しさのあま り、ホームシックという呼吸困難にかかりはじめていた」と吐露している。それ に共鳴を覚えて、〈2〉における「寂しさ」が生じて、日本語教材を通じて語法と寂 寥感を内包する一首を獲得したと言えよう。

蔡華山の指導(創作と論文)を受けた李巫秀珠「点建堂撰『台湾万葉百人一首』之時 代意義」27によると、「更に若くて優秀な日本の和歌作家である俵万智を学校に招 待して指導していただくこともできる」という提案をしている。蔡華山采も「俵万 智の口語和歌が一番よい教材を提供してくれている」と強調している。残念なが ら、待望されるままいまだに実現されていないが、李巫秀珠 ${ }^{29}$ は現実的に「俵万 智の和歌を教材にして、大学の日本語学科に「和歌クラブ」を作れば、皆で和歌を 楽しめるようになるのではないだろうか」と、蔡の指導路線に追随する決意を示 している。

\section{2 華語流行楽壇}

『サラダ記念日』が台湾における日本語文学圈外の人々にも共感を呼び起こす に到った原因としては、次の中国語訳本四点の果たした役割が重要である。
〈1〉文経社編訳群(訳)『沙拉紀念日』(1988、台北：文経)
〈2〉張澄(編)『沙拉紀念日』(1990、台北：世茂) [中英対照]
〈3〉蔡雅娟(訳)『沙拉紀念日』(2002、台北：新雨)
〈4〉陳系美(訳)『沙拉紀念日』(2018、台北：大田)

〈1〉については、「誤訳」と「訳漏孔」30という二大問題を抱えていると言わざる をえない。文経社の呉栄斌 31 社長によると、「俵のスタイルが好きな台湾作家が すでに数人いて、類似した作品を創作した。そのうちレコードと歩調を合わせ て出版した人がいて、良い成績を上げている」という。その一例として、筆者は 「『沙拉紀念日』与『味道』32という短文で、1994年に歌手の辛曉琪がリリースした CDアルバム「味道」を挙げたうえで、表 1 における(1) (7)を取り上げ、特に(1) (4)は『サラダ記念日』の思い出す君の手君の背君の息脱いだまんまの白い鞉下から 換骨奪胎したものだと推測したことがある。それを立証するために、もっと詳 しく論拠を提出せ补ばならない。ヒットソングとなった同名の「味道」は、中国 語流行音楽界で大家とされる姚謙(1961 )の作詞だが、姚謙『一個人的品味』33を見 れば、その歌詞を書くことになった「源」は次の通りである。
25 注7, p.18.

26 国際学友会日本語学校 編著『進学日本語中級』 1(台北：大新, 2002)， p.31.

27 『日文化』21(中国文 化大学日文系日研所, 2002.5), p.215. 原文： 「甚至可邀請日本年軽 優秀的和歌作者俵万智 来校指導」

28 『万葉集』と『台湾万 葉集』の比較的考察— 生活歌の諧謔性につ いて」(『中日文化』22， 中国文化大学日文系日 研所, 2003.5), p.234.

29 『台湾万葉集』の研究」 （台北：中国文化大学修 士論文, 2003), p.110.

30 頼衍宏「《沙拉紀念日》 的中訳問題」(『静宜語文 論叢』12-1, 静宜大学外 語学院, 2019.6), p.73.

31 余元君 (訳)『風的手掌』 (台北: 文経社, 1991), p p. 10-11. 所収。原 文：「対俵小姐的一些 感受与NEWS一従「沙 拉紀念日」談起」。原 文：「台湾也有幾位作 家喜歓這種詩作風格, 創作了類似的作品。尤 其有一位還配合唱片出 版, 締造了很好的成績

32 『和流』4 (銘伝大学応用 日語学系, 2002.5), p.15.

33 (台北: 時報文化, 2013), pp. 25-26. 原文：「歌 詞的来源」有一回我得 了重感冒, 反応的病理 状態就是嚴重的鼻塞 「失去嗅覚譲我対很多 事情的反応変得極為混 沌」「那一周我就掉到了 一個没有味道的地獄裡 「這也譲我開始回想許 多的感情経験, 貌似也 与味道息息相関」特別 是愛情, 於是我用這様 的感想写了這首歌」 
34 小新『毎一首歌都有 $\mathrm{TA}$ 要去的地方』(上海：上 海文化, 2015), p.164. 原文:「《味道》, 創 作過程更是無趣」

35 亀井俊介編『現代の比 較文学』(東京：講談 社, 1994), p.132. 所 収小堀桂一郎「材源研 究の意味一芥川龍之 介・里見弶・その他

36 盧虹貝「木心文学創作 中的“文本再生”現象研 究」(南京：南京大学 修士論文, 2014), p.3 p.40. 原文：「本文所 述“文本再生”, 是指作 者以他人的文字作品 (原文本) 作為原材料, 在此基礎上進行程度 較小的改写, 形成自己 的作品 (再生文本)。 「在一些再生文本中, 木心不僅不作出提示 還故意営造出“原創” (即不存在“文本再生”) 的仮象。此類情況, 筆 者名之為“反向暗示”」

37 原歌：「思い出寸君の 手君の背君の息脱い だまんまの白い靴下」 (注7, p.117.)

38 尤静波編著『現代音楽 教育叢書 中国流行音 楽通論』(北京：大衆文 芸, 2011), p.230.

39 袁青「姚謙死迷川久保 玲 偶爾出軌偶爾放肆 (『聯合報』1997年7月 12日) 47面. 原文：「歌 詞「味道」」「透着耐人 尋味的余韻
重い風邪をこじらせたために、ひどい鼻づまりになってしまい、嗅覚を 失ってしまった。その一週間、匂いのない地獄に落ちてしまった。そこで 色々な感情の経験が思い起こされ、それらは匂いと密接な関係にあるらしく 見えた。特に恋の方面であり、故にこのような感想でこの歌を書き上げ た。

そうした「創作過程はいっそうつまらない」34と評されているが、「かくれた る材源の存在」35はないだろうか。中国現代作家木心(1927 2011)の手法を参考に すると、研究者である盧虹貝が定義したとおりその「「テキスト再生」とは、作者 が他人の書いた著作物(原文)を原材料とし、それを多少なりとも書き換えて自分 の著作物(再生テキスト)を形作るプロセスを指す」。また、「少しの再生テクス卜 の中に、木心は提示しないどころか、わざとオリジナル制作(すなわち「テクスト 再生」なし)の仮象を造出する。かかる場合、筆者は「逆方向暗示」と名づける」 ${ }^{36}$ と いう指摘もある。木心の状況と同じように、姚謙の材源が他所にある可能性はあ りそうだ。リフレーンだけを訳本く1〉における関連作品と並べてみよう。（下線 は筆者による。以下同じ)

\section{表1「味道」の材源}

\begin{tabular}{|c|c|c|}
\hline & 「味道」 & 〈1〉『沙拉紀念日』(頁) \\
\hline (1) & 想念你的笑 & 在人潮中突然想起你說的笑話, 不知不覺笑出聲來。（57） \\
\hline (2) & 想念你的外套 & $\begin{array}{l}\text { 悄悄穿起沾著你的味道的外套. 故意擺出詹姆斯狄恩慣有的動作。 } \\
\text { (56) }\end{array}$ \\
\hline (3) & 想念你白色襪子 & 看著你到處亂扔的白襪子, 想起你的手、你的呼吸、你的臉。 (76) \\
\hline (4) & 和你身上的味道 & $\begin{array}{l}\text { 海風中夾雜著你的味道, 突然被你抱在懷中的我，有如貝殼般地僵 } \\
\text { 硬。(29) }\end{array}$ \\
\hline (5) & 我想念你的吻 & 下午五點半，我們在沙灘上追逐擁吻，遠山含笑俯看。（29） \\
\hline (6) & 和手指淡淡煙草味道 & $\begin{array}{l}\text { 我愛你為我剝牡礪設而滲著淡淡血色的手。(28) } \\
\text { 偶爾才吸一口的香煙, 也有令人無法了解的煙霧。(96) }\end{array}$ \\
\hline (7) & 記憶中曾被愛的味道 & $\begin{array}{l}\text { 你用過的梳子穿透我的髮梢, 耳際隱約泛著男人的味道。（30） } \\
\text { 被愛的記憶有些透明，我還是單身一個人。(111) }\end{array}$ \\
\hline
\end{tabular}

四回ほど繰り返される「想念你的」は、(3)の「看著你到處亂扔的白褿子, 想起你 的手、你的呼吸、你的臉」37を摄取した跡が認められる。思い慕われる人の「笑」外 套」「白色襪子」「身上的味道」「吻」「手指淡淡煙草味道」「記憶中曾被愛的味道」という 七大特徵も、例外なく俵の歌々に詠久込まれた事物に他ならない。つまり、俵の ユニークな語彙・語法を踏まえつつ練り上げられたのが「味道」の世界なのではな いだろうか。1995年、「味道」は「香港十大中文金曲奨」の「優秀国語歌曲奨——金 奨」38に輝いた。当該歌詞については、「味わい深い余韻を残す」39とコメントさ 
れているが、小論の指摘により『サラダ記念日』からの巧みな素材の借用が明ら かになり、それによってその余韻は一層深みを増し得た、というべきである。

女心の代弁者として華語音楽界の名手になった姚謙は、またイギリスのレ コード会社EMI百代の総支配人を兼任する一時期があった。その傘下に所属した 歌手として許茹芸が知られる。姚は許の新ボスになったという記事 ${ }^{40}$ が確かめら れるが、その間に許の詩集『此時快楽的代価』(2002、台北：紅色文化)が上梓され た。劉衛莉「許茹芸的詩 紅到日本 風格酷似女詩人俵万智 日商想翻訳 泰人也有意 41 によると、「許の詩風は「俵万智」と近くて、感情がこまやかで意味深い」と日本の 出版社に讃えられた許は、心の中ではひそかに喜んだあまり、「『サラダ記念日』 を読んだことがあり、俵の作品が好きだ」と豪快に打ち明け、『サラダ記念日』を 許常徳から贈られた後、自分でも複数の訳本を購入したうえで読んでいる」とい う読書遍歴を言明している、という。許の白話詩のうち、代表的な一首「(誦, 你 的體味)」42を取り上げてみよう。

一種很適合你的香味
那曾經 是
我 喜歡男人 的 味道
塗抹在 你 的肌膚
讓 酒精香水
滲入你的血液
再從 你 喘息後的汗水
揮發
經過 我的嗅覺
融合成一種
很適合你的 體味

表1における訳本く1>の29・30・56頁を見ると、「你的味道」という共通した キーワードがある。それを取り入れたのが、許の「你的」味道」ではないだろう か。しかも28頁の「我愛你」と許の「我喜歡」「你」を吟味すると、程度の差こそあ れ相手に好ましい感情を抱くのは同じである。この一件から、訳本を媒介とし て『サラダ記念日』が華語詩壇にも新風を吹き込んだことが確認できる。姚謙自身 の作詞と、周辺歌手の詩作と相俟って、俵調が中国語流行楽壇内外にわたって影 響を及ぼしていた実態はほぼ明白になった。ちなみに、2014年11月27日に、「短 歌」という名を冠して売り出された中国語不定型詩集一鍾立風『短歌集=Tanka』 (2014、桂林：広西師範大学出版社)のために、姚謙は北京の対外経貿大学に赴 き、この詩人と対談を交わしている。現代の中国でも、姚は短歌のよき理解者と して認められているのである。
40 許若薇「許茹芸走過坎 坷路」( 『中時晚報』 2001年6月18日) 17面. 原文：「許茹芸的新老 闆」

41 「聯合報」2003年6月9 日, D1面. 原文: 「日 本書商看到後很喜歓, 主動与她聯繋, 洽談翻 訳成日文版的計画」「対 方認為她的風格, 跟日 本一位女詩人俵万智 很接近, 情感都相當細 倵深刻。她聴了心裡 暗自骞喜, 「我読過她 的詩集『沙拉紀念日』, 很喜歓她的東西。」她 透露, 第一本「沙拉紀 念日」是発行専輯「日 光機場」時, 当時的企 画許常徳送給她的, 後 来她自己又買了不同 的訳本来看。

42『此時快楽的代価』(台 北：紅色文化, 2002), p.58. 和訳すると、次 のようになるだろう。 (誦する、君の体臭 を)

君にとても合った一 種の香り/あれは か つて/あたし 好きな 男の 味/お肌に 塗 りノアルコール・香 水を/打血に滲み込 ませ/それから君 喘いだ後の汗から 揮発する/私の嗅覚 を経て/溶け合って 一種の/とても君に 合った 体臭になる 
43『猝合文学』406(聯合 文学雑誌社, 2018.8) p.41. 原文：「読過以 下三十本書告白無往不 利」「《沙拉紀念日》。 俵万智」

44『台湾出版与閲読』7(国 家図書館, 2019.9), p.63. 原文：「1987年 俵万智著《沙拉紀念 日》詩集，累計銷售 250万冊」

『サラダ記念日』が出てから三十年以上経過した。しかし、決して風化しては いない。孫梓評「孫梓評的告白教戦索引」43の萀めによると、恋人に告白したけれ ば最適な中文図書三十冊のうち、俵万智『サラダ記念日』がリストアップされてい る。また、林宜和「日本戦後出版業鳥瞰」44にも「1987年、俵万智が書いた詩集「サ ラダ記念日」は250万部を売り上げた」という紹介がある。今後、どのような俵万 智の色彩を帯びた流行歌が出るのだろうか、期待をかけてもさほど無駄ではな さそうな気がする。

\section{3 おわりに}

短歌はすでに日本文壇では非主流のジャンルとされているが、台湾文壇には 想像もつかないほどの浸透力を持っているのではないだろうか。台湾の事例か ら分かるのは、ライトバースが台湾の短歌界内部に新たな選評基準を提供したば かりか、俵万智と直接に交流を深め、短歌の産出をも促している点である。学生 の場合、歌作りに堪能な教授の支援と助力を得ながら、『サラダ記念日』の秀歌を お手本として相次いで真似て、ある水準に達した短歌を発表することができる ようになった。芸能界を見ても、俵万智調のライトバースが翻訳を媒介として 作詞家によって巧妙に新作中に織り込まれていた。結果、一般大衆も短歌ゆかり の流行歌を間接的ながら享受できた。俵万智の短歌は大衆文化の一部を支えてい た、知られざる原資だったと言えよう。

付記 本稿は台中科技大学「2018亜洲中的日本一従人文・社会・経貿看日本」(2018年5月25日)での口 頭発表を加筆修正したものである。

\section{参考文献 (Bibliography)}

蔡華山(2003)「『万葉集』と『台湾万葉集』の比較的考察一生活歌の諧譃性について」第22号, p.234、Tsai. Hua-shan (2003) Comparative Studies between "Manyosyu" and "Taiwan Manyosyu"--The Badinage in Daily Life. Chinese And Japanese Culture Vol.22, p.234.

彭春陽 (2002)「日本的国民女歌人俵万智」第6号, p.114. Perng. Chun-young (2002) Japan’s national female tanka poet Tawara Machi. World Literature Vol.6. p.114.

李巫秀珠 (2002)「呉建堂撰『台湾万葉百人一首』之時代意義」第21号, p.215, Li Wu. Shou-chu(2002)： The Historical Significane of Taiwan Hyakunin Isshu Selected by Wu Chen Tuang. Chinese And Japanese Culture Vol.21, p.215. 